\title{
ADENOVIRUS INFECTION IN CATS. AN EPIDEMIOLOGICAL SURVEY IN THE CZECH REPUBLIC
}

\author{
B. LAKATOS ${ }^{1,2}$, Z. KNOTEK ${ }^{3}$, J. FARKAS ${ }^{4}$, É. ÁDÁM ${ }^{4}$, O. DOBAY ${ }^{4}$, I. NÁSZ
}

${ }^{1}$ University of Veterinary Sciences, ${ }^{2}$ Lakat-Vet BT., Budapest, Hungary

${ }^{3}$ University of Veterinary and Pharmaceutical Sciences, Brno, Czech Republic

${ }^{4}$ Institute of Microbiology, Semmelweis Medical University, Budapest, Hungary

Received July 8, 1999

Accepted September 7, 1999

\begin{abstract}
Lakatos B., Z. Knotek, J. Farkas, É. Ádám, O. Dobay, I. Nász: Adenovirus Infection in Cats. An Epidemiological Survey in the Czech Republic. Acta Vet. Brno 1999, 68: 275-280.

The widespread presence of adenoviruses in various species makes it probable that a carrier state and infection also exist in cats; this could be proved earlier. On the basis of these considerations investigations were carried out to perform an epidemiological survey in 100 randomly selected feline sera from the Czech Republic. Antibody detection was carried out in a group-specific indirect ELISA employing purified adenovirus hexon antigen. The adenovirus seropositivity was found to be $25 \%$ among the samples tested. Domestic short-haired cats $(28 \%)$ and females $(34 \%)$ showed increased infection rates. Among the 6 retrovirus-infected cats 3 males with outdoor access were seropositive. Cats showing respiratory and gastrointestinal symptoms gave high prevalence. These results are similar to those found in other species and feline populations and reflect on the natural adenovirus infection of cats in the Czech Republic.
\end{abstract}

Feline, antibody, adenovirus

Since the first isolation of adenoviruses (Rowe et al. 1953; Hilleman and Werner 1954) about 130 serotypes have been described from different mammalian and avian species (Boros et al. 1985; Mautner 1989; Russell et al. 1995). Presence of adenoviruses has been verified by histopathology and electron microscopy (Ishibashi and Yasue 1984) in poikilotherm species, such as amphibians (Clark et al. 1973), reptiles (Jacobson 1986), and even in fish (Jensen and Bloch 1980). Adenoviruses are grouped in two genera on the basis of their origin and genus-specific antigens. The Mastadenovirus genus includes serotypes isolated from humans and mammals, while adenoviruses coming from birds belong to the Aviadenovirus genus (Russell et al. 1995). Occurrence of mastadenoviruses has been verified by isolation and characterization in 9 mammalian species apart from the humans (Russell et al. 1995). The actual number of adenoviruses in a given species depends rather on the effort made on isolation than on the frequency of occurrence (Wadell 1984). Grouping of adenoviruses of animal origin is generally done after the host species, e.g. simian, canine, bovine, ovine, rabbit and so on (B artha and Áldássy 1964; Belák and Pálfi 1974; Bodon et al. 1979; Belák 1980; Baber and Condy 1981; Ishibashi et al. 1984; Adair et al. 1986).

Up till now, adenoviruses have not been isolated from cats or other Felidae, although their presence had been demonstrated. The presence of adenovirus was proved in a cat by light and electron microscopy (Kennedy and Mullaney 1993). Only one case of adenovirus infection in Felidae (black panther) was published. The suspicion of an adenovirus infection arose from the pathological changes and histopathology (Gupta 1978). On the basis of experience with other species, one can presume that subclinical infections also occur in cats. A serosurvey has been performed on samples from different European countries, where the infection rate was found to be 10-20\% (Lakatos et al. 1996). Detection of adenovirus hexon 
gene sequences was successful from a single adenovirus seropositive cat suffering from hepatic failure (Lakatos et al. 1999). Clinical signs of a systemic adenovirus infection may be expected more frequently in cats with acquired or congenital immunodeficiency (B arker and van Dreumel 1985; Dungworth 1985). Since the host spectrum of adenoviruses is rather narrow (Timoney et al. 1988), a genuine adenovirus of cats may be expected.

The feline leukaemia virus (FeLV) and the feline immunodeficiency virus (FIV) have been isolated worldwide as the causative agents of acquired immunodeficiency in cats (Matteucci et al. 1993; Beebe et al. 1994), and the occurrence of the latter virus infection has also been diagnosed in Hungary (Lakatos et al. 1992).

Adenoviruses play a relevant pathological role frequently in HIV-infected humans (S abin et al. 1999) and certain human adenovirus serotypes were isolated exclusively from patients suffering from HIV infection (Hierholzer 1992). These facts also suggest the possible existence of a genuine adenovirus in cats.

In our experiments, the presence of specific antibodies to adenovirus antigens was demonstrated in cats. The aims of this study were: 1 . to detect adenovirus infection in cats originating from the Czech Republic, and 2. to trace groups/populations where infection is accumulated.

\section{Materials and Methods}

To detect antibodies against adenovirus antigens, altogether 100 serum samples were tested. These feline sera collected from cats throughout the Czech Republic (mainly from Prague, Brno and Ostrava regions) originated from the serum bank of the Small Animal Clinic at the University of Veterinary and Pharmaceutical Sciences, Brno, Czech Republic. As history data breed, sex (male or female), age (years) of the cats, access to outdoor (kept outdoor or indoor), clinical status, the reason for clinical examination and qualitative results of the feline immunodeficiency virus (FIV), and feline coronavirus (FCoV) antibody detection and feline leukaemia virus (FeLV) antigen detection (positive or negative) were included in the study. The proportion of castrated animals was low (8\%), so they were not grouped separately. FIV, FeLV and FCoV tests were performed with commercially available reagents.

As adenovirus group-specific ELISA antigen purified human adenovirus type 1 (HAdV-1) hexon antigen was prepared. HAdV-1 was propagated on HEp-2 cells, and the soluble antigens were purified by repeated anion exchange chromatography on DEAE Sephadex A-50 (Pharmacia, Sweden) (Ádám et al. 1988). In indirect ELISA experiments (Lakatos et al. 1996), wells of 96-well polystyrene plates (Falcon) were coated with purified HAdV-1 hexon antigen at $20 \mu \mathrm{g} / \mathrm{ml}$ final concentration. The antigen, the serial dilution of sera, the biotin conjugate (BiotinantiCat, Sigma), the streptavidin-HRPO conjugate (Extravidin, Sigma), the substrate (OPD), as well as the $2 \mathrm{M}$ $\mathrm{H}_{2} \mathrm{SO}_{4}$ used for stopping the reaction were applied in $50 \mu \mathrm{l}$ quantities. Washing between the subsequent steps was carried out with PBS. The optical density (OD) was measured at $492 \mathrm{~nm}$ wavelength in an Anthos 2010 spectrophotometer. When evaluating the results 4 x OD of the negative control serum was taken as cut-off. The history data and the adenovirus serological test results were evaluated using chi-square tests and Fisher's exact tests.

\section{Results}

In indirect ELISA, 25\% of the studied feline serum samples showed positive reaction with the adenovirus hexon antigen being in accordance with other results (Lakatos et al. 1996). The $95 \%$ confidence interval for the population was between 17 and $34 \%$. With rising age the seropositivity rose from $17 \%$ to $41 \%$ (Table 1). This difference between age groups was significant $(\mathrm{p}=0.0480)$. Under 1 year of age the adenovirus antibody prevalence was higher $(57 \%)$, but the statistical sample was only based on the results of 7 cats. Domestic shorthaired cats and cats with outdoor access gave higher rates $(28 \%)$ compared with persians $(20 \%)$. The seropositivity among female cats was $34 \%$, while males gave a lower prevalence with $18 \%$. The mean age of the seronegative and seropositive cats was the same with 3.1 years. The 6 retrovirus-infected cats (1 FIV-infected and 5 FeLV-infected ones) showed higher prevalence: 3 males ( 1 FIV positive and 2 FeLV positive) with outdoor access tested seropositive for adenovirus $(50 \%)$, while 22 samples of the 94 retrovirus negative animals tested adenovirus positive $(23 \%)$. The FCoV serological status was available in the case of 61 animals, and 4 of the 12 coronavirus antibody carrier animals tested adenovirus 
Table 1

History data of cats included in the adenovirus study

\begin{tabular}{|c|c|c|c|c|c|}
\hline \multicolumn{2}{|l|}{ Characteristics } & \multirow{2}{*}{$\begin{array}{c}\text { AdV (-) } \\
46 \\
27 \\
2\end{array}$} & \multirow{2}{*}{$\begin{array}{c}\text { AdV (+) } \\
18 \\
7 \\
0\end{array}$} & \multirow{2}{*}{$\begin{array}{c}\mathbf{A d V}(+) \% \\
28 \\
20 \\
0\end{array}$} & \multirow{2}{*}{$\begin{array}{c}\mathbf{P} \\
0.076\end{array}$} \\
\hline Breed & \begin{tabular}{|l|} 
Domestic \\
Persian \\
Exotic \\
\end{tabular} & & & & \\
\hline Sex & \begin{tabular}{|l} 
Male \\
Female \\
\end{tabular} & $\begin{array}{l}48 \\
27\end{array}$ & $\begin{array}{l}11 \\
14\end{array}$ & $\begin{array}{l}18 \\
34\end{array}$ & 0.076 \\
\hline Kept & $\begin{array}{l}\text { Outdoor } \\
\text { Indoor }\end{array}$ & $\begin{array}{l}45 \\
30\end{array}$ & $\begin{array}{r}18 \\
7\end{array}$ & $\begin{array}{l}28 \\
18\end{array}$ & 0.290 \\
\hline FIV & $\begin{array}{l}\text { Positive } \\
\text { Negative }\end{array}$ & $\begin{array}{r}0 \\
75\end{array}$ & $\begin{array}{r}1 \\
24\end{array}$ & $\begin{array}{r}100 \\
24\end{array}$ & $\mathrm{ND}$ \\
\hline FeLV & \begin{tabular}{|l} 
Positive \\
Negative
\end{tabular} & $\begin{array}{r}3 \\
72\end{array}$ & $\begin{array}{r}2 \\
23\end{array}$ & $\begin{array}{l}40 \\
24\end{array}$ & ND \\
\hline Retrovirus & $\begin{array}{l}\text { Positive } \\
\text { Negative }\end{array}$ & $\begin{array}{r}3 \\
72\end{array}$ & $\begin{array}{r}3 \\
22\end{array}$ & $\begin{array}{l}50 \\
23\end{array}$ & 0.130 \\
\hline FCoV & \begin{tabular}{|l|} 
Positive \\
Negative \\
\end{tabular} & $\begin{array}{r}8 \\
37 \\
\end{array}$ & $\begin{array}{r}4 \\
12 \\
\end{array}$ & $\begin{array}{l}33 \\
24\end{array}$ & 0.550 \\
\hline Source of cats & \begin{tabular}{|l|} 
Brno \\
Ostrava \\
Prague \\
\end{tabular} & $\begin{array}{r}56 \\
13 \\
6 \\
\end{array}$ & $\begin{array}{r}17 \\
4 \\
4 \\
\end{array}$ & $\begin{array}{l}23 \\
23 \\
40\end{array}$ & 0.528 \\
\hline Clinical satus & \begin{tabular}{|l|} 
Healthy \\
FeLUTD \\
Cat flu \\
GI disease \\
Diabetic \\
\end{tabular} & $\begin{array}{r}35 \\
17 \\
10 \\
9 \\
4 \\
\end{array}$ & $\begin{array}{l}6 \\
2 \\
8 \\
9 \\
0 \\
\end{array}$ & $\begin{array}{r}15 \\
10 \\
44 \\
50 \\
0\end{array}$ & 0.003 \\
\hline Reason for test & $\begin{array}{l}\text { Preventive } \\
\text { Stationary } \\
\text { Ambulant }\end{array}$ & $\begin{array}{l}34 \\
23 \\
18\end{array}$ & $\begin{array}{r}7 \\
10 \\
8\end{array}$ & $\begin{array}{l}17 \\
30 \\
30\end{array}$ & 0.319 \\
\hline Age group & $\begin{array}{l}0-1 \mathrm{yr} \\
1-2 \mathrm{yrs} \\
3-5 \mathrm{yrs} \\
6-15 \mathrm{yrs}\end{array}$ & $\begin{array}{r}3 \\
34 \\
32 \\
7\end{array}$ & $\begin{array}{l}4 \\
7 \\
8 \\
5\end{array}$ & $\begin{array}{l}57 \\
17 \\
20 \\
41\end{array}$ & 0.048 \\
\hline
\end{tabular}

$\mathrm{ND}=$ not done because of small sample size

seropositive (33\%). The group of 49 animals negative for FCoV antibodies was close to the average adenovirus antibody prevalence with $24 \%$. All these differences were not significant $(\mathrm{p}>0.05)$ between the adenovirus seropositive and seronegative groups in breed $(\mathrm{p}=0.420)$, sex $(\mathrm{p}=0.076)$, access to outdoor $(\mathrm{p}=0.290)$, retrovirus serological status $(\mathrm{p}=$ $0.130)$ and FCoV infection $(p=0.550)$. The source of the samples and the reason for testing did not have any influence on the results $(p=0.528$ and $p=0.319$, respectively). The clinical status of the cats tested showed significant differences $(\mathrm{p}=0.003)$. Cats with respiratory and gastrointestinal symptoms gave high rates with 44 and 50\%, respectively.

\section{Discussion}

Adenoviruses belonging to Mastadenovirus genus have a common, so-called genusspecific antigen (Wigand et al. 1982; Hierholzer et al. 1987; Wadell 1988; Hierholzer 1989; Horwitz 1990; Hierholzer et al. 1991) detectable by different serological methods employing polyclonal or monoclonal antibodies (Ádám et al. 1985). This genus-specific determinant is present on the hexon of adenoviruses, and this is why purified hexon preparation was used as antigen to study the presence of antibodies against adenovirus in cats. On the basis of our results in indirect ELISA experiments $25 \%$ of 
randomly selected cats were found to harbour adenovirus hexon antibodies. The retrovirusinfected cats had an adenovirus antibody prevalence of $50 \%$. However, their number was too small to draw conclusions, but on the other hand it suggests the existence of a specific relation between FIV/FeLV and adenovirus infections in cats as it is known between HIV and adenovirus infections in humans (Hierholzer 1992; Sabin et al. 1999). These findings need further investigation to be interpreted correctly. The seropositivity was higher in females (34\%) being close to be significant and in cats with outdoor access (28\%). This latter fact can be explained by the more intensive contact between cats resulting in elevated infection pressure. No significant differences could be detected except for age distribution and clinical status of the cats tested. The elevated prevalence in age group $0-1 \mathrm{yr}(57 \%)$ is probably not related to specific maternal antibodies, because all but one cats in this group were over 6 months of age. Cats with feline lower urinary tract disease (FeLUTD) and diabetes mellitus gave low rates, whereas cats with respiratory and gastrointestinal signs showed high adenovirus antibody prevalence. This may generate questions about the pathological role of an adenovirus in cats, but the number of the cats was too low to interpret this finding properly. It is not easy to increase the sample size, because of limited access to large serum banks which are capable of providing proper history data. The other cause for the lack of significant differences may be the even distribution of adenovirus infection in cats.

However, it seems to be evident that cats can be infected by adenovirus(es) naturally, and this was confirmed in the samples from the Czech Republic, too. Based on the relevant literature adenovirus infection can lead to pathological conditions among certain predisposing conditions (Khoo et al. 1995). Our results suggest the same in cats, but further investigation and confirmation are needed. The presence of adenovirus(es) in cats - beside being a potential pathogen - may be relevant among future SPF exclusion criteria and in FIV vaccination studies using recombinant adenovirus as vector (Gonin et al. 1995). This work is the first detailed adenovirus epidemiological study performed in cats based on relevant history data.

\section{Adenovirová infekce u koček. Epidemiologická studie v České Republice}

Adenoviry byly v minulosti prokázány u širokého spektra živočichů. Předpoklad, že se mohou vyskytovat rovněž u koček a vyvolávat u nich infekce, již byl též potvrzen. V souladu s těmito skutečnostmi byla provedena studie založená na vyšetření 100 náhodně vybraných vzorků krve, odebraných od koček v České republice. Průkaz protilátek proti adenoviru byl realizován nepřímým ELISA testem využívajícím purifikovaný adenovirový antigen. Ve vyšetřovaném souboru bylo prokázáno $25 \%$ seropozitivních vzorků. Vyšší zastoupení pozitivních koček bylo zjištěno u plemene domácí krátkosrstá $(28 \%)$ zejména samičího pohlaví (34\%). Ve vyšetřovaném souboru byla u šesti koček prokázána přítomnost retroviru, $\mathrm{z}$ toho u tří kocourů s neomezeným pohybem mimo chov. Vyšší prevalence adenoviru byla zjištěna u koček vykazujících onemocnění dýchacího a trávicího aparátu. Prokázané skutečnosti jsou ve shodě s výsledky dosaženými u ostatních živočišných druhů i jiných populací koček a potvrdily výskyt adenovirové infekce u koček v České republice.

\section{Acknowledgements}

The authors are grateful to Bendinelli, M. (Italy), Egberink, H. F. (The Netherlands), Jarrett, O. (Scotland) and Pedersen, N. C. (USA) for providing moral help to the successful completion of the project.

The research program was supported by the grants No. 17052 and 23619 of the Hungarian Research Fund (OTKA) and the Hungarian Academy of Sciences (TKI).

\section{References}

ADAIR, B.M., McKILlOP, E. R., COACKLEY, B. H. 1986: Serological identification of an Australian adenovirus isolate from sheep. Austr. Vet. J. 63: 162-165 
ÁDÁM, É., NÁSZ, I., LENGYEL, A., ERDEI, J., FACHET, J. 1985: Differentiation of adenovirus hexon epitopes with monoclonal antibodies in gel diffusion assays. Mol. Immunol. 22: 967-971

ÁDÁM, É., NÁSZ, I., LENGYEL, A., ERDEI, J., FACHET, J. 1988: Determination of different antigenic sites on the adenovirus hexon using monoclonal antibodies. Arch. Virol. 93: 261-271

BABER, D. J., CONDY, J. B. 1981: Isolation of bovine adenovirus type 3, 4 and 8 from free living African buffaloes (Syncerus caffer). Res. Vet. Sci. 31: 69-75

BARKER, I. K., VAN DREUMEL, A. A. 1985: The Alimentary System. In: JUBB, K.V.F., KENNEDY, P. C., PALMER, N. (eds): Pathology of Domestic Animals. $3^{\text {rd }}$ ed. Vol 2, Academic Press, Orlando, pp 116-117

BARTHA, A., ÁLDÁSSY, P. 1964: Isolation of adenovirus strains from calves with diarrhoea. Acta Vet. Acad. Sci. Hung. 14: $239-244$

BEEBE, A. M., FAITH, T. G., SPARGER, E. E., TORTEN, M., PEDERSEN, N. C., DANDEKAR, S. 1994: Evaluation of in vivo and in vitro interactions of feline immunodeficiency virus and feline leukemia virus. AIDS 8: $873-878$

BELÁK, S. 1980: Properties of ovine adenoviruses. Acta Vet. Acad. Sci. Hung. 28: 47-55

BELÁK, S., PÁLFI, V. 1974: An adenovirus isolated from sheep and its relationship to type 2 bovine adenovirus. Arch. ges. Virusforsch. 46: 366-369

BODON, L., PROHÁSZKA, L., ÁDÁM, É., NÁSZ, I. 1979: Isolation of an adenovirus from rabbits. Acta Vet. Acad. Sci. Hung. 27: 73-75

BOROS, G., GRAF, Z., BENKÕ, M., BARTHA, A. 1985: Isolation of a bovine adenovirus from fallow deer (Dama dama). Acta Vet. Acad. Sci. Hung. 33: 119-123

CLARK, H. F., MICHALSKI, F., TWEEDELL, K. S., YOHN, D., ZEIGEL, R. F. 1973: An adenovirus, FAV-1, isolated from the kidney of a frog (Rana pipiens). Virology 51: 392-400

DUNGWORTH, D. L. 1985: The respiratory system. In: JUBB, K. V. F., KENNEDY, P. C., PALMER, N. (eds): Pathology of Domestic Animals. $3^{\text {rd }}$ ed. Vol 2, Academic Press, Orlando, pp 532-551

GONIN, P., FOURNIER, A., OUALIKENE, W., MORAILLON, A., ELOIT, M. 1995: Immunization trial of cats with a replication-defective adenovirus type 5 expressing the ENV gene of FIV. Vet. Microbiol. 45: 393-401

GUPTA, P. P. 1978: Inclusion body hepatitis in black panther (Panthera pardus pardus). Zbl. Vet. Med. B. 25: 858-860

HILLEMAN, M. R., WERNER, J. H. 1954: Recovery of new agent from patiens with acute respiratory illness. Proc. Soc. Exp. Biol. Med. 85: 183-188

HIERHOLZER, J. C. 1989: Adenoviruses. In: SCHMIDT, N. J., EMMONS, R. W. (eds): Diagnostic procedures for viral, rickettsial and chlamydial infections. $6^{\text {th }}$ ed., American Public Health Association, Washington, D.C., pp. 219-264

HIERHOLZER, J. C., JOHANSSON, K. H., ANDERSON, L. J., TSOU, C. J., HALONEN, P. E. 1987: Comparison of monoclonal time-resolved fluoroimmunoassay with monoclonal capture/biotinylated detector enzyme immunoassay for adenovirus antigen detection. J. Clin. Microbiol. 25: 1662-1667

HIERHOLZER, J. C., STONE, Y. D., BRODERSON, J. R. 1991: Antigenic relationship among the 47 human adenoviruses determined in reference horse antisera. Arch. Virol. 121: 179-197

HIERHOLZER, J. C. 1992: Adenoviruses in the immunocompromised host. Clin. Microbiol. Rev. 5: 262-274

HORWITZ, M. S. 1990: Adenoviridae and their replication. In: FIELDS, B. N., KNIPE, D. M., CHANOCK, R. M., HIRSCH, M. S., MELNICK, J. L., MONATH, T. P., ROIZMAN, B. (eds): Virology $2^{\text {nd }}$ ed., Raven Press, New York, pp. 1679-1721

ISHIBASHI, M., YASUE, H. 1984: Adenoviruses of animals. In: GINSBERG, H.S. (ed): The adenoviruses. Plenum Press, New York and London, pp 497-562

JACOBSON, E. R. 1986: Viruses and viral associated diseases of reptiles. In: BELS, V. L., VAN DEN SANDE, A. P. (eds): Maintenance and reproduction of reptiles in captivity. Vol. 2 Acta Zool. et Pathol. Antverp. 79: 73-90

JENSEN, N. J., BLOCH, B. 1980: Adenovirus-like particles associated with epidermal hyperplasia in cod (Gadus morhua). Nord. Vet. Med. 32: 173-175

KENNEDY, F. A., MULLANEY, T. P. 1993: Disseminated adenovirus infection in a cat. J. Vet. Diagn. Invest. 5: 273-276

KHOO, S. H., BAILEY, A. S., DE JONG, J. C., MANDAL, B. K. 1995: Adenovirus infection in human immunodeficiency virus-positive patients: clinical features and molecular epidemiology. J. Infect. Dis. 172: 629-637

LAKATOS, B., FARKAS, J., ÁDÁM, É., JARRETT, O., EGBERINK, H. F., BENDINELLI, M., NÁSZ, I., ONGRÁDI, J. 1996: Data to adenovirus infection of European cats. Magyar Állatorvosok Lapja (Hungarian Veterinary Journal) 51: 543-545

LAKATOS, B., FARKAS, J., EGBERINK, H. F., VENNEMA, H., HORZINEK, M. C., BENKÕ, M. 1999: Detection of adenovirus sequences from a cat by PCR. Acta Veterinaria Hungarica, submitted for publication

LAKATOS, B., LUTZ, H., BEREGI, A. 1992: Feline immunodeficiency virus (FIV) infection of cats. A serosurvey in Hungary. Magyar Állatorvosok Lapja (Hungarian Veterinary Journal) 47: 213-215

MATTEUCCI, D., BALDINOTTI, F., MAZETTI, P., PISTELLO, M., BANDECCHI, P., GHILARDUCCI, R., POLI, A., TOZZINI, F., BENDINELLI, M. 1993: Detection of feline immunodeficiency virus in saliva and plasma by cultivation and polymerase chain reaction. J. Clin. Microbiol. 31: 494-501 
MAUTNER, V. 1989: Adenoviridae. In: PORTFIELD, J. S. (ed): Andrewes' Viruses of vertebrates. Bailliére and Tindall, London, pp 249-282

ROWE, W. P., HUEBNER, R. J., GILMORE, L. K., PARROTT, R. H., WARD, T. G. 1953: Isolation of a cytopathogenic agent from human adenoids undergoing spontaneous degeneration in tissue culture. Proc. Soc. Exp. Biol. Med. 84: 570-573

RUSSELL, W. C., ADRIAN, T., BARTHA, A., FUJINOGA, K., GINSBERG, H. S., HIERHOLZER, J. C., DE JONG, J. C., LI, Q. G., MAUTNER, V., NÂSZ, I., WADELL, G. 1995: Adenoviridae. In: Virus Taxonomy. Sixth report on the International Committee on taxonomy of viruses. Arch. Virol. Suppl. 10: 128-133

SABIN, C. A., CLEWLEY, G. S., DEAYTON, J. R., MOCROFT, A., JOHNSON, M. A., LEE, C. A., MCLAUGHLIN, J. E., GRIFFITHS, P. D. 1999: Shorter survival in HIV-positive patients with diarrhoea who excrete adenovirus from the GI tract. J. Med. Virol. 58: 280-285

TIMONEY, J. F., GILLESPIE, J.H., SCOTT, F. W., BARLOUGH, J. E. 1988: Hagan and Burner's microbiology and infectious diseases of domestic animals. $8^{\text {th }}$ ed. Cornell University Press, Ithaca, NY, pp. 532-551

WADELL, G. 1984: Molecular epidemiology of human adenoviruses. In: DOERFLER, W. (ed.): Current Topics in Microbiology and Immunology, vol 110, The molecular biology of adenoviruses. Springer Verlag, New York, pp. $191-220$

WADELL, G. 1988: Adenoviridae: The adenoviruses In: LENNETTE, E. H., HALONEN, P. MURPHY, F. A (eds): Laboratory diagnosis of infectious disease: principles and practice. Vol II. Viral, rickettsial and chlamydial diseases. Springer Verlag, New York, pp. 284-300

WIGAND, R., KELLER, D., WERLING, I. 1982: Immunological relationship among human adenoviruses of subgenus D. Arch. Virol. 72: 199-209 